\title{
Detection of SARS-CoV-2 using five primer sets
}

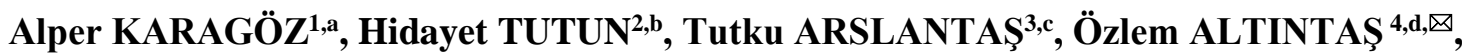 \\ Nadir KOÇAK ${ }^{5, \mathrm{e}}$, Levent ALTINTAŞ 6,f
}

\begin{abstract}
${ }^{1}$ Uşak University, Department of Molecular Biology and Genetics, Uşak; ${ }^{2}$ Burdur Mehmet Akif Ersoy University, Faculty of Veterinary Medicine, Department of Pharmacology and Toxicology, Burdur; ${ }^{3}$ Çankırı Public Hospital, Microbiology Laboratory, Çankırı; ${ }^{4}$ Veterinary Control Central Research Institute, Ankara; ${ }^{5}$ Selçuk University, Medical Genetics, Konya; ${ }^{6}$ Ankara University, Faculty of Veterinary Medicine, Department of Pharmacology and Toxicology, Ankara, TURKEY ${ }^{\mathrm{a}}$ ORCID: 0000-0002-8178-223X; ${ }^{\mathrm{b}}$ ORCID: 0000-0001-9512-8637; ${ }^{\mathrm{c}}$ ORCID: 0000-0002-4351-6600; ${ }^{\mathrm{d}}$ ORCID: 0000-0001-6467-9647; ${ }^{\mathrm{e}}$ ORCID: 0000-0002-1727-1582; ${ }^{\mathrm{f}}$ ORCID: 0000-0002-5148-723X
\end{abstract}

Corresponding author: ozlembayram@ hotmail.com Received date: 30.07.2020 - Accepted date: 13.09.2020

\begin{abstract}
A novel coronavirus (SARS-CoV-2) outbreak, responsible for a pneumonia-associated respiratory disorder (COVID19), has started in early December 2019 in Wuhan, China, and has rapidly spread around the world. Rapid and accurate diagnostic testing plays a crucial role in tackling the COVID-19 pandemic. In this study, it was aimed to compare 5 primer sets designed to amplify different regions for the detection of SARS-CoV-2 and to perform sequence analysis. Conventional RT-PCR was carried out using primers targeting different regions of the virus genome including ORF1ab, Envelope (E), RNA-dependent RNA polymerase (RdRp), Spike (S) and Nucleocapsid (N) genes for the diagnosis of COVID-19. DNA sequence of ORF1ab gene from each sample were compared with the DNA sequence data of SARS-CoV-2 stored in the GenBank and ORF1ab phylogenetic tree was constructed. The amplicon sizes of ORF1ab, S, E, N and RdRp genes were 588 bp, 440 bp, 145 bp, 323 bp and 196 bp, respectively. The SARS-CoV-2 RNA was detected from $74 \%$ of total samples from RdRp gene, $87 \%$ for $\mathrm{N}$ gene, $74 \%$ for S gene, $61 \%$ for E gene and $82 \%$ for ORF1ab region. The ORF1ab sequences of SARS-CoV-2 from 82 patients were had $100 \%$ identity to the sequence of Wuhan isolate and among themselves. The phylogenetic analysis revealed that all isolates formed a cluster. The results of this study suggest that the $\mathrm{N}$ region is the best for SARS-CoV-2 identification.
\end{abstract}

Keywords: Conventional RT-PCR, COVID-19, Diagnosis, E gene, N gene, ORF1ab.

\section{SARS-CoV-2'nin beș primer seti kullanılarak belirlenmesi}

Özet: Pnömoni ile ilişkili solunum bozukluğundan (COVID-19) sorumlu yeni bir koronavirüs (SARS-CoV-2) salgını Aralık 2019'un başında Çin'in Wuhan şehrinde başladı ve hızla dünyaya yayıldı. Hızlı ve doğru teşhis testleri COVID-19 salgını ile mücadelede çok önemli bir rol oynar. Bu çalışmada SARS-CoV-2'nin saptanması için farklı bölgelerinin amplifiye edilmesi amacıyla tasarlanmış 5 primer setin karşılaştırılması ve sekans analizinin yapılması amaçlanmıştır. Konvansiyonel RT-PCR, COVID-19 tanısı için ORF1ab, Zarf (E), RNA-bağlı RNA polimeraz (RdRp), Spike (S) ve Nükleokapsid (N) genleri içeren virüs genomunun farklı bölgelerini hedefleyen primerler kullanıldı ve ORF1ab geninin DNA dizisi, GenBank SARS-CoV-2 DNA dizisi verileri ile karşılaştırılarak, ORF1ab filogenetik ağacı oluşturuldu. ORF1ab, S, E, N ve RdRp genlerinin amplikon boyutları, sırasıyla 588 bp, 440 bp, 145 bp, 323 bp ve 196 bp idi. Toplam örneklerin \%74'ünde RdRp geni, \%87'sinde N geni, \%74'ünde S geni, \%61'inde E geni ve \%82'sinde ORF1ab geni tespit edildi. 82 hastadan SARS-CoV-2'nin ORF1ab dizileri, Wuhan izolat dizisi ve kendi aralarında \%100 özdeşliğe sahipti. Filogenetik analiz, tüm izolatların bir küme oluşturduğunu ortaya çıkarmıştır. Bu çalışmanın sonuçları, $\mathrm{N}$ bölgesinin SARS-CoV-2 tespiti için en iyisi olduğunu göstermektedir.

Anahtar Kelimeler: COVID-19, E geni, Konvansiyonel RT-PCR, N geni, ORF1ab, Tan1.

\section{Introduction}

Coronaviridae is a family of enveloped, positive sense and single-stranded ribonucleic acid (RNA) viruses, with a large genome between 27-31 kilobases in size (23). Coronaviruses have been identified in a wide range of hosts, including birds and mammals, and can cause respiratory, enteric, hepatic and neurological diseases of varying severity $(12,25,26,29)$. A novel human-infecting coronavirus (COVID-19), named Severe Acute Respiratory Syndrome Coronavirus-2 (SARS-CoV-2), emerged in December 2019, in Wuhan, China, and has spread rapidly throughout the world (32). Most of the 
patients infected with the coronavirus develop clinical manifestations including fever, difficulty in breathing, cough, and chest radiographs showing invasive lesions of both lungs $(5,9)$. Multiple organ failures and death can be observed in severe cases (24).

Until today, no treatments have been found for treating SARS-CoV-2. However, several options including antiviral drugs such as Favipirarvir, Lopinavir, Ritonavir (3), anti-inflammatory agents such as Baricitinib, Ruxolitinib, Fedratinib (19) and other drugs such as chloroquine (18) have been used to improve clinical symptoms of the infection $(30,31)$.

In COVID-19 Guide of Turkey Ministry of Health (21), it is suggested to immediately start hydroxychloroquine (HCQ) treatment on patients with a probability of COVID-19, along with several other antiviral drugs. Oseltamivir was used with HCQ in March and April but was discontinued. Favipiravir or Remdesivir has been used in cases with progressing pneumonia or clinical signs becoming severe as an additional agent. Also, anticoagulants agents and monoclonal antibodies such as Tocilizumab are used in intensive-care units for patients with COVID-19 related pathologies such as thrombosis.

Coronavirus genome consists of 6-11 open reading frames (ORFs) encoding 27 proteins. ORF1ab constitutes about two-thirds of the whole genome length, encoding a total of 16 nonstructural proteins (nsps) and remaining one-third of the genome encodes four structural proteins and at least six accessory proteins $(11,28)$. The main structural proteins are Spike surface glycoprotein (S), Membrane (M), Nucleocapsid protein (N), Envelope (E) and accessory proteins (ORF3, ORF4a, ORF4b, ORF5, and ORF8b) encoded by ORFs (4). For conducting the PCR assays, these target proteins can be utilized for the SARS-CoV-2 diagnosis. Currently, real-time reverse transcription-polymerase chain reaction (RT-PCR) assay has been developed to rapidly detect the SARS-CoV-2 and used in clinics. RT-PCR assay, based on measuring the amount of amplified product with various primers and probe sets designed to the target in SARS-CoV-2 genome, is sensitive and suitable to detect the viruses in samples of sputum, throat swab and secretions from the upper respiratory tract $(2,7,13)$.

In this study, it was aimed to confirm the diagnosis of COVID-19 in a hundred of samples from COVID-19 positive patients using sequence analysis and compare the five primer sets designed to amplify of different regions of SARS-CoV-2 for detecting the virus.

\section{Materials and Methods}

Permission to publish this study was obtained from the by Republic of Turkey Ministry of Health, General Directorate of Health Services (T13-27-31). The study was approved by the ethic committee of Burdur Mehmet
Akif Ersoy University (Ethic approval Code: GO2020238).

Samples: Patients who were admitted to Çankırı Public Hospital with complaining of symptoms including fever, cough, sore throat and trouble breathing were evaluated for SARS-CoV-2 using RT-qPCR detection kit (Biospeedy-USA Technologies Inc. COVID-19 RT-qPCR Detection Kit v2.0, Istanbul-Turkey). Oropharyngeal and nasopharyngeal swabs samples of one hundred of consecutive patients (55\% male; $45 \%$ female) with confirmed SARS-CoV-2 from June 1 to July 20, 2020, were used for all analysis in this study.

One Step RT-PCR: One step RT-PCR kit (Qiagen, Germany) was used to amplify genes including ORF1ab, S, E, N and RNA depended on RNA Polymerase (RdRp) using specific primers $\left(5^{\prime}\right.$-CTA GGA CCT CTT TCT GCT CA-3' and 5'-ACA CTC TCC TAG CAC CAT CA3' for ORFlab gene, 5'-CCC TGT TGC TAT TCA TGC AG-3' and 5'-CCC TAT TAA ACA GCC TGC AC-3' for S gene, 5'-GGA AGA GAC AGG TAC GTT AA-3' and 5'-AAG GTT TTA CAA GAC TCA CG-3' for E gene, 5'CCT CTT CTC GTT CCT CAT CA-3' and 5'-CCT GGT CCC CAA AAT TTC CT-3' for N gene, and 5'-CAT CTC ACT TGC TGG TTC CT-3' and 5'-CCT TAA TAG TCC TCA CTT CTC TC-3' for RdRp gene) designed by Mollaei et al. (14). Conventional RT-PCR was performed in a $20 \mu 1$ reaction buffer contained $15 \mu 1$ of $2 \times$ Master Mix and $5 \mu 1$ of nucleic acid extract. Amplification was carried out using the CFX Connect real-time system (BioRad Laboratories, Hercules, CA, USA) with the following program: $5 \mathrm{~min}$ at $52^{\circ} \mathrm{C}$ for reverse transcription, 10 secs at $95^{\circ} \mathrm{C}$ for activation of the Taq DNA polymerase, and 40 cycles of $1 \mathrm{~s}$ at $95^{\circ} \mathrm{C}$ and $30 \mathrm{~s}$ in $55^{\circ} \mathrm{C}$. PCR amplicons were analyzed by electrophoresis in $2 \%$ agarose gel (BioRad, USA) with a molecular size marker 100bp.

Sequencing and phylogenetic analysis: Following the amplification of ORF1ab gene from each sample, twoway sequencing reactions were carried out with the primers used for PCR reactions. For DNA sequence analysis; ABI Prism 3700 Genetic Analyzer (Thermo Fisher Scientific, Massachusetts, USA) and BigDye Terminator V3.1 Cycle Sequencing Kit (Applied Biosystems, California, USA) were used with the manufacturer's recommendation. The DNA sequence data of samples were compared with the DNA sequences data of SARS-CoV-2 stored in the GenBank using the Basic Local Alignment Search Tool (BLAST version 2.0) program. Multiple sequence alignments of ORF1ab genes were carried out using the 588 coding nucleotide sequences obtained from 100 SARS-CoV-2 isolates and the sequences of isolate Wuhan-12-1-1399-458/2020 (GenBank accession number MT544308.1) by the ClustalW2 program for determination of homology between the studied isolates and the references isolates from Wuhan. ORF1ab phylogenetic tree was constructed 
using the neighbor-joining method within the Molecular Evolutionary Genetics Analysis software (MEGA; version 4.0).

\section{Results}

All SARS-CoV-2 positive patients exhibited several clinical manifestations including cough, fever, sore throat and difficulty in breathing. Among all patients with SARS-CoV-2, 20 patients were hospitalized due to severe pneumonia, and a total of 5 patients had an admission in the intensive-care unit and no death was observed among them. The reaction products generated by specific primers for each gene region were separated on $2 \%$ agarose gel and presented in Figure 2. The amplicon sizes of ORF1ab, S, E, N and RdRp genes were 588 bp, 440 bp, 145 bp, 323 bp and 196 bp, respectively. The SARS-CoV-2 RNA was detected from $74 \%$ of total samples from RdRp gene, $87 \%$ for $\mathrm{N}$ gene, $74 \%$ for $\mathrm{S}$ gene, $61 \%$ for $\mathrm{E}$ gene and $82 \%$ for ORF1ab region (Figure 1).

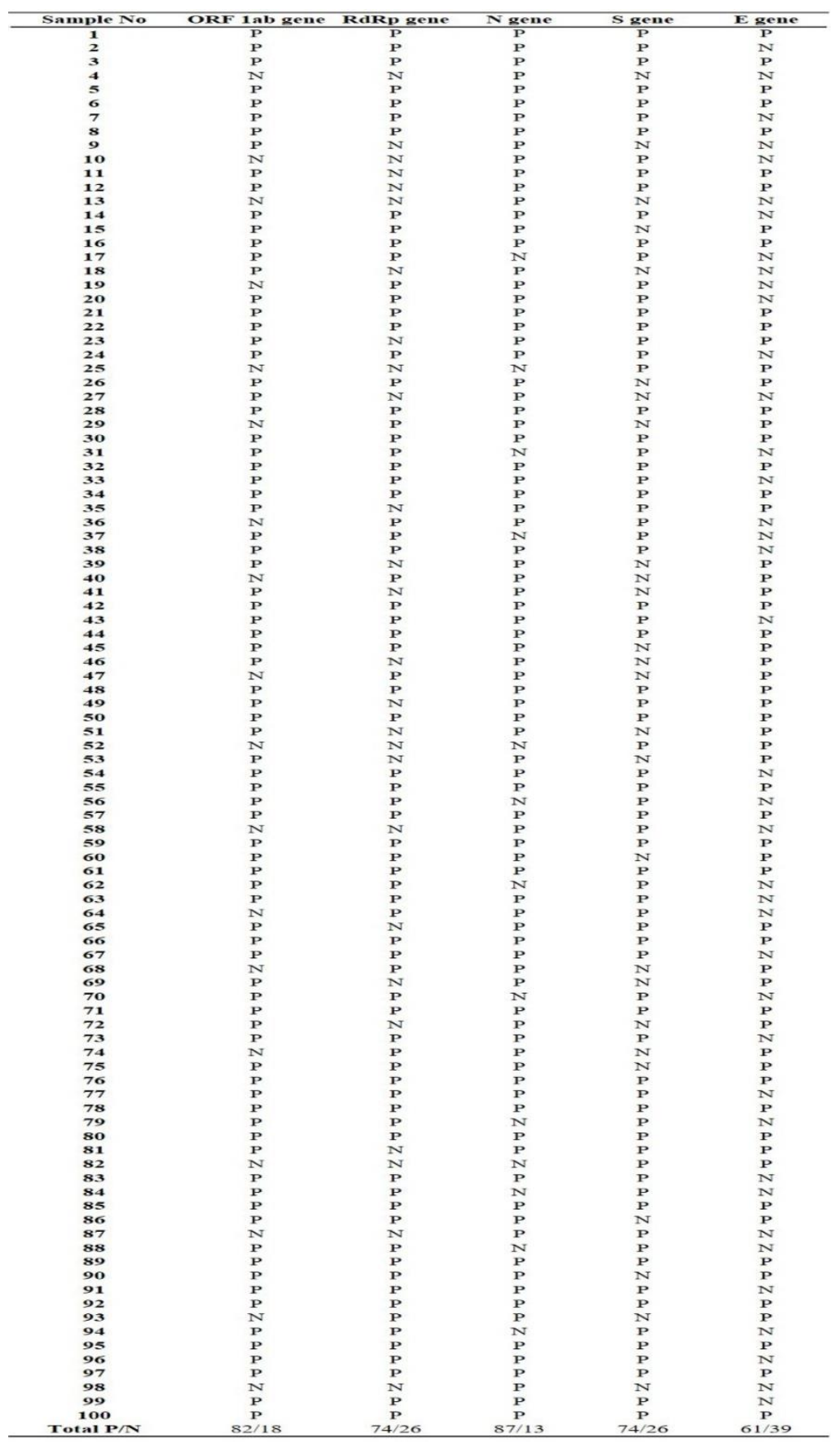

Conventional RT-PCR for N (Nucleocapsid), RdRp (RNA depended RNA Polymerase), E (Spike glycoprotein), S (Surface protein) gene, P: Positive, N: Negative.

Figure 1. Conventional RT-PCR results in different genes of SARS-CoV-2 samples. 


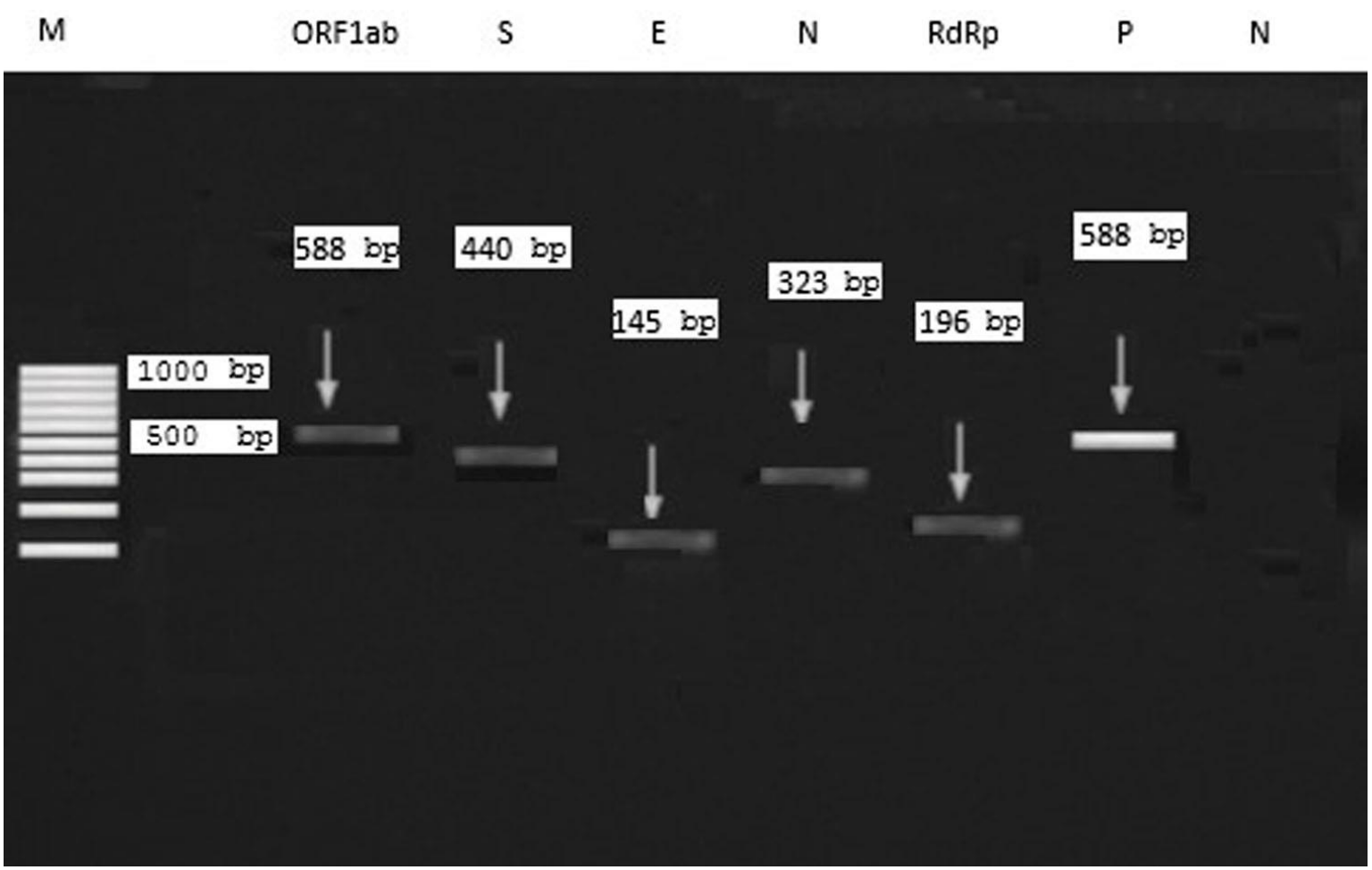

Figure 2. Agarose gel electrophoresis (2\%) of 5 PCR products. Lane M: Size marker (100 bp); ORF1ab: 588 bp; S gene: 440 bp; E gene: 145 bp; N gene: 323 bp; RdRp: 196 bp, P: positive; N: Negative.

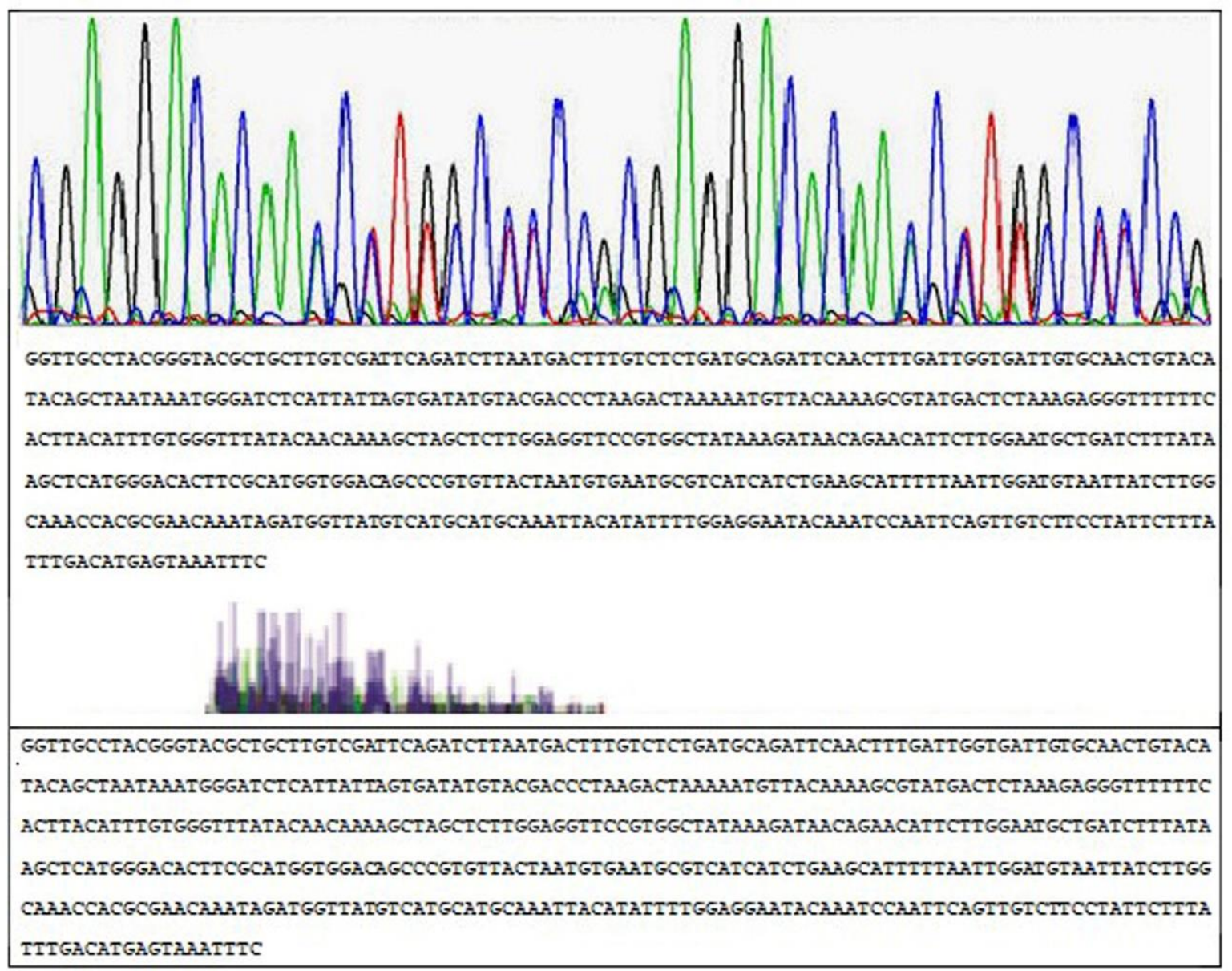

Figure 3. Sequence analysis peak of ORF1ab obtained from patients. 


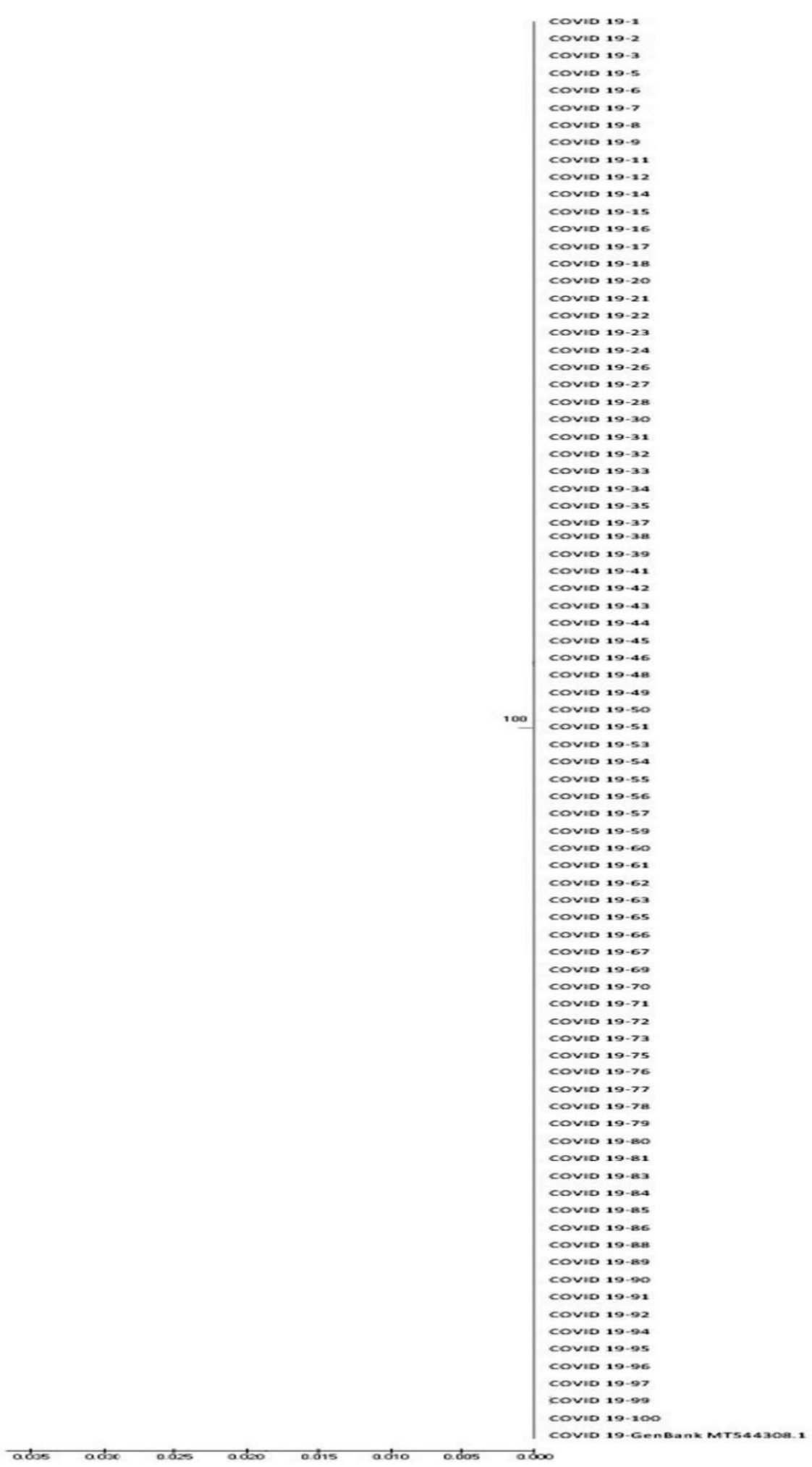

Figure 4. Phylogenetic relations among COVID-19 genotypes detected in patient with COVID-19. The phylogenetic tree was constructed by the neighbor-joining method.

After the sequencing of amplicons, the sequences were analyzed using the BLAST program. The sequence image related to ORF1ab gene was given as peaks in Figure 3. BLAST analysis of the ORF1ab gene sequences confirmed the identity of all 100 Turkish isolates as SARS-CoV-2. Wuhan-12-1-1399-458/2020 (GenBank accession number MT544308.1) was used as the reference genome for ORF1ab. The ORF1ab sequences of SARSCoV-2 from all the patients had $100 \%$ identity to the sequence of the Wuhan isolate and among themselves. The phylogenetic analysis revealed that all isolates formed a cluster (Figure 4). 


\section{Discussion and Conclusion}

The coronavirus COVID-19 has spread to 213 countries and territories around the world and two international conveyances with 28989073 confirmed cases, including 925373 deaths, as of September 13, 2020 (27). As of 13 September 2020, the total number of confirmed cases of COVID-19 reached to 289635 and the death toll has reached 6999 in Turkey (17). The death rate $(2.42 \%)$ in Turkey is lower than most of the developed countries in the world. Turkey has been quite effective in reducing the viral spread due to establishing a scientific committee, consisting of academics, at the earlier time of COVID-19 outbreak by the Turkish Government and effective and preventative measures taken in line with the recommendations of the committee. Also, Turkey successfully has kept the mortality rate very low with its a large amount of intensive-care unit (ICU) beds, wellqualified and trained staff in ICU, strong free-of-charge health service and a successful treatment strategy against COVID-19 outbreak (10).

Currently, no vaccines or specific medications is available for preventing or treating COVID-19. However, there are several drug options to have better treatment outcomes either as mono or combination therapy. The drugs being used to help manage the clinical manifestations of COVID-19 are chloroquine and its metabolite HCQ, azithromycin, monoclonal antibodies such as Tocilizumab, anticoagulants such as heparin, corticosteroids and several antiviral agents including Lopinavir, Ritonavir (15). Medical professionals in Turkey started using aggressive treatments and medication strategies for treating COVID-19 much earlier than Western counties. Briefly, each adult patient confirmed with SARS-CoV-2 is initially treated with HCQ and azithromycin. Also, Oseltamivir was used with HCQ and was discontinued after April 2020. Favipiravir or Remdesivir have been started to use in patients with severe pneumonia. Tocilizumab treatment has been used in ICU for patients with severe COVID-19 related cytokine release syndrome. Also, anticoagulant drugs were added to the treatment algorithm to treat the coagulopathy observed in patients hospitalized with COVID-19 and related to mortality as well $(10,21)$. The drugs or drug combinations used in the treatment of patients with COVID-19 in Turkey are generally recommended in COVID-19 treatment. Therefore, the causes of Turkey's success in COVID-19 may be its strong health care system and to take precautions much earlier than most of the affected countries by the COVID-19 outbreak.

The clinical signs caused by COVID-19 in patients are not specific and cannot be used for an accurate diagnosis. Nucleic Acid Amplification Tests (NAAT) such as RT-PCR and Chest-computed tomography (CT) have been used for diagnosis and screening COVID-19.
NAAT for the detection of viral nucleic acids are more convenient, reliable and better than syndromic testing and CT scans (1). A large number of RT-PCR kits have been designed for detection SARS-CoV-2 genetically. Several sets of primer and probes were designed to amplify a number of molecular targets including RdRp gene, E gene, $\mathrm{S}$ gene, ORF1ab and $\mathrm{N}$ gene for real-time RT PCR assays (22). It has been reported that the RdRp and the E gene had high analytical sensitivity for the detection of SARS$\mathrm{CoV}-2$, whereas the $\mathrm{N}$ gene was slightly less sensitive (6). One study showed that the $\mathrm{N}$ gene was to be performing well for SARS-CoV-2 diagnosis (8). Another study showed that the ORF1ab, $\mathrm{N}$ and RdRp primers had sensitivity, specificity and positive predictive value higher than other primer (S gene, E gene) (14). In this study, the primers designed by Mollaei et al. (14) were used for diagnosis of SARS-CoV-2 RNA from the patients and the $\mathrm{N}$ gene $(87 \%)$ had high analytical sensitivity for detection of SARS-CoV-2, whereas the ORF1ab gene was slightly less sensitive $(82 \%)$. Therefore, the best gene for identifying cases of SARS-CoV-2 is the N gene, ORF1ab is the second-best option after this gene. A commercial kit, Bio-Speedy, used for detecting SARS-CoV-2, is carried out by RT-qPCR targeting the virus-specific RdRp gene region. In the present study, only 74 of the 100 samples confirmed with the commercial kit measuring using the RdRp gene region in the hospital could be verified by using primers for the RdRp gene region analysis. The reason for this difference in results may be the difference of the primers used for the detection of the gene region and the laboratory conditions.

Sequencing molecular methods such as nextgeneration sequencing are currently impractical for diagnosis of SARS-CoV-2 but may be used for determination mutations and epidemiological analysis of SARS-CoV-2 (16, 20). Epidemiologically, sequences alignments of ORF1ab gene showed that 82 patients in our study had $100 \%$ identity to the sequence of Wuhan isolate and among themselves, suggesting that they might have been infected with the virus from the infection source at the market in Wuhan, China.

In conclusion; the conventional RT-PCR assay with $\mathrm{N}$ and ORF1ab primers was the best option for detecting for SARS-CoV-2 in patients. The ORF1ab gene sequences of SARS-CoV-2 positive samples were $100 \%$ identical to the Wuhan genome reference.

\section{Financial Support}

This research received no grant from any funding agency/sector.

\section{Conflict of Interest}

The authors declared that there was no conflict of interest. 


\section{References}

1. Alsuliman T, Sulaiman R, Ismail S, et al (2020): COVID19 paraclinical diagnostic tools: Updates and future trends. Curr Res Transl Med. 68, 83-91.

2. Bustin SA, Nolan T (2020): RT-qPCR testing of SARSCoV-2: a primer. Int J Mol Sci, 21, 3004.

3. Cai Q, Yang M, Liu D, et al (2020): Experimental treatment with favipiravir for COVID-19: an open-label control study. Engineering.

4. Chen B, Tian EK., He B, et al (2020): Overview of lethal human coronaviruses. Signal Transduct Tar, 5, 1-16.

5. Chen N, Zhou M, Dong X, et al (2020): Epidemiological and clinical characteristics of 99 cases of 2019 novel coronavirus pneumonia in Wuhan, China: a descriptive study. The Lancet, 395, 507-513.

6. Corman VM, Landt O, Kaiser M, et al (2020): Detection of 2019 novel coronavirus (2019- $n \mathrm{CoV})$ by real-time $R T$ PCR. Eurosurveillance, 25, 2000045.

7. Emery SL, Erdman DD, Bowen MD, et al (2004): Realtime reverse transcription-polymerase chain reaction assay for SARS-associated coronavirus. Emerg Infect Dis, 10, 311-316.

8. Holshue ML, DeBolt C, Lindquist S, et al (2020): First case of 2019 novel coronavirus in the United States. N Engl J Med, 36, 929-936.

9. Kilic AU, Kara F, Alp E, et al (2020): New threat: 2019 novel Coronavirus infection and infection control perspective in Turkey. North Clin Istanb, 7, 95-98.

10. Kodaz H (2020): Editorial: Successful Treatment Strategy of Turkey against Covid-19 Outbreak. EJMO, 4, 177-178.

11. Kumar S, Nyodu R, Maurya VK, et al (2020): Morphology, Genome Organization, Replication, and Pathogenesis of Severe Acute Respiratory Syndrome Coronavirus 2 (SARSCoV-2). 23-31. In: SK Saxena (Ed) Coronavirus Disease 2019 (COVID-19). Springer, Singapore.

12. Luan J, Lu Y, Jin X, et al (2020): Spike protein recognition of mammalian ACE2 predicts the host range and an optimized ACE2 for SARS-CoV-2 infection. Biochem Biophys Res Commun, 526, 165-169.

13. Mathuria JP, Yadav R (2020): Laboratory diagnosis of SARS-CoV-2- a review of current methods. J Infect Public Heal, 13, 901-905.

14. Mollaei HR, Afshar AA, Kalantar-Neyestanaki D, et al (2020): Comparison five primer sets from different genome region of COVID-19 for detection of virus infection by conventional RT-PCR. Iran J Microbiol, 12, 185-193.

15. Omolo CA, Soni N, Fasiku VO, et al (2020): Update on therapeutic approaches and emerging therapies for SARSCoV-2 virus. Eur J Pharmacol, 883, 173348.

16. Rodríguez-Morales AJ, Balbin-Ramon GJ, Rabaan AA, et al (2020): Genomic Epidemiology and its importance in the study of the COVID-19 pandemic. InfezMed, 2, 139142.

17. Sağlık Bakanlığı (2020): Genel Koronavirus Tablosu. Available at https://covid19. saglik.gov.tr/TR-66122/genelkoronavirus-tablosu.html (Accessed September 13, 2020).
18. Singh AK, Singh A, Shaikh A, et al (2020): Chloroquine and hydroxychloroquine in the treatment of COVID-19 with or without diabetes: A systematic search and a narrative review with a special reference to India and other developing countries. Diabetes Metab Syndr, 14, 241-246.

19. Stebbing J, Phelan A, Griffin I, et al (2020): COVID-19: combining antiviral and anti-inflammatory treatments. Lancet Infect Dis, 20, 400-402.

20. Tang YW, Schmitz JE, Persing DH, et al (2020): Laboratory diagnosis of COVID-19: current issues and challenges. J Clin Microbiol, 58, e00512-20.

21. The Republic of Turkey Ministry of Health (2020): COVID-19 (SARS-CoV-2 Infection) Guide. July 17, 2020. Available at https://hsgm.saglik.gov.tr/en/covid-19-ingilizce-dokumanlar/rehberler.html. (Accessed July 20, 2020).

22. Udugama B, Kadhiresan P, Kozlowski HN, et al (2020): Diagnosing COVID-19: the disease and tools for detection. ACS Nano, 14, 3822-3835.

23. Wei Q, Wang Y, Ma J, et al (2020): Description of the First Strain of 2019-nCoV, C-Tan-nCoV Wuhan StrainNational Pathogen Resource Center, China, 2020. China CDC Weekly, 2, 81-82.

24. Weiss P, Murdoch DR (2020): Clinical course and mortality risk of severe COVID-19. The Lancet, 395, 10141015.

25. Woo PC, Lau SK, Lam CS, et al (2012): Discovery of seven novel Mammalian and avian coronaviruses in the genus deltacoronavirus supports bat coronaviruses as the gene source of alphacoronavirus and betacoronavirus and avian coronaviruses as the gene source of gammacoronavirus and deltacoronavirus. J Virol, 86, 3995-4008.

26. Woolhouse M, Scott F, Hudson Z, et al (2012): Human viruses: discovery and emergence. Philos T R Soc B, 367, 2864-2871.

27. Wordometers (2020): COVID-19 Coronavirus Pandemic. Available at https://www.worldometers.info/coronavirus/ (Accessed September 13, 2020).

28. Yang D, Leibowitz JL (2015): The structure and functions of coronavirus genomic $3^{\prime}$ and 5' ends. Virus Res, 206, 120133.

29. Yoldar ZA, Koç BT, Oğuzoğlu TÇ (2020): Phylogenetic analysis of partial transmembrane protein gene of canine coronaviruses detected in Turkey. Ankara Univ Vet Fak Derg, 67, 265-271.

30. Yousefifard M, Zali A, Ali KM, et al (2020): Antiviral therapy in management of COVID-19: a systematic review on current evidence. Arch Acad Emerg Med, 8, e45.

31. Zhang J, Zhou L, Yang Y, et al (2020): Therapeutic and triage strategies for 2019 novel coronavirus disease in fever clinics. Lancet Respir Med, 8, e11-e12.

32. Zhu H, Wei L, Niu P (2020): The novel coronavirus outbreak in Wuhan, China. Global Health Research and Policy, 5, 1-3. 